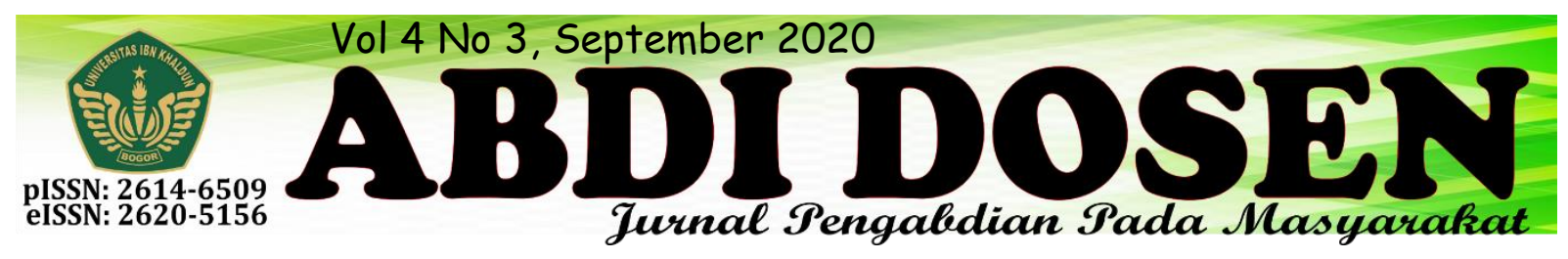

\title{
UPAYA PENINGKATAN KAPASITAS DAN LITERASI KESEHATAN MASYARAKAT (PHBS) SANTRI MELALUI KOMUNIKASI, INFORMASI, DAN EDUKASI (KIE) DI PESANTREN WADI MUQODDAS DI PONDOK MEJA PROVINSI JAMBI
}

\author{
Asparian $^{1}$, La Ode Reskiaddin ${ }^{2}$, David Kusmawan ${ }^{3 *}$, M.Ridwan $^{4}$ \\ david.kusmawan@unja.ac.id* \\ Program Studi Ilmu Kesehatan Masyarakat, Fakultas Kedokteran dan Ilmu Kesehatan, \\ Universitas Jambi, Indonesia. ${ }^{1234}$
}

\begin{abstract}
ABSTRAK
Pondok pesantren di Indonesia menghadapi tantangan kesehatan masyarakat serupa yakni rentannya santri dari terpaparnya penyakit menular seperti scabies, ISPA, gastritis, diare, muntaber, thifoid, hepatitis A, cacar, keracunan makanan (food poisoning), sampai penyakit demam berdarah. Hal tersebut masih belum menjadi perhatian bagi beberapa warga pesantren, masyarakat sekitar pesantren ataupun pihak pemerintah. Berdasarkan hasil survey awal di Pesantren Wadi Muqoddas, aspek perilaku terutama higiene personal santri di pesantren tersebut masih kurang. Selain itu, lingkungan pondok pesantren tersebut juga belum bersih dan sehat karena masih banyak sampah sampah yang berserakan. Hal tersebut dapat menjadi faktor risiko tempat berkembangbiaknya nyamuk. Salah satu strategi yang dapat dilakukan adalah promosi kesehatan melalui KIE. Edukasi tersebut bertujuan meningkatakan pengetahuan santri mengenai PHBS dan berpengaruh terhadap perilaku sehat santri. Selain itu, melalui peningkatan kapasitas santri juga dapat meningkatkan keterampilan santri dalam berperilaku sehat. Kegiatan pengabdian kepada masyarakat ini dilakukan mulai dari tahap persiapan hingga tahap evaluasi. Output yang diharapkan dalam pengabdian kepada masyarakat ini adalah peningkatan literasi kesehatan mengenai PHBS dan peningkatan kapasitas dalam santri dalam pemantauan jentik nyamuk. Kegiatan dilakukan selama 3 hari. Pelaksanaan hari pertama mengenai edukasi Perilaku Hidup Bersih dan Sehat. Sebelum pelaksanaan edukasi, santri diberikan pre-test mengenai PHBS untuk mengetahui presentasi pengetahuan mereka sebelum terpapar informasi mengenai PHBS. Berdasarkan hasil pre-test diperoleh tingkat pengetahuan santri sebesar 50\%. Literasi mengenai PHBS juga terbilang rendah. Hal ini disebabkan kurangnya paparan informasi yang didapatkan mengenai PHBS. Berdasarkan hasil wawancara juga menyebutkan bahwa sebagian besar belum mengetahui PHBS dan baru pertama kali mendapatkan informasi tersebut. Setelah diberikan intervensi berupa edukasi menunjukkan peningkatan pengetahuan sebesar $90 \%$. Hal ini menunjukkan terjadi perbedaan tingkat pengetahuan sebelum dan sesudah dilakukan edukasi. Penerapan promosi kesehatan masyarakat melalui komunikasi, informasi, dan edukasi (KIE) merupakan salah satu langkah praktis dan tepat untuk meningkatkan kapasitas dan literasi kesehatan masyarakat di bidang Perilaku Hidup Bersih dan Sehat santri Pesantren Wadi Muqoddas Pondok Meja, Provinsi Jambi. Selain itu agar program KIE ini bisa terus berlanjut maka langkah-langkah seperti
\end{abstract}


pemberdayaan, pembentukan, dan penguatan kader santri untuk meneruskan praktik dan ilmu pengetahuan ini kepada sebayanya sangatlah diperlukan.

Kata Kunci : Perilaku Hidup Bersih Sehat, KIE, pesantren, jumantik, literasi kesehatan masyarakat

\section{PENDAHULUAN}

Banyak persoalan kesehatan yang dihadapi oleh pondok pesantren di Indonesia baik masalah kesehatan hygiene personal maupun masalah kesehatan lainnya. Pondok pesantren tersebut sebagian besar menghadapi tantangan serupa yakni rentannya santri dari terpaparnya penyakit menular seperti scabies, ISPA, gastritis, diare, muntaber, thifoid, hepatitis A, cacar, keracunan makanan (food poisoning), sampai penyakit demam berdarah.

Hal tersebut masih belum menjadi perhatian bagi beberapa warga pesantren, masyarakat sekitar pesantren ataupun pihak pemerintah. Ada beberapa yang menjadi dasar penyebab dari buruknya kualitas dari kehidupan santri di seluruh pesantren di Indonesia yaitu karena sifat atau perilaku hidup sederhana yang ditunjukkan oleh masyarakat pondok pesantren sesuai tradisi dan subkultural yang sudah ada dan berkembang semenjak pesantren berdiri. Selain itu, kurangnya fasilitas-fasilitas yang dimiliki oleh pesantren untuk menunjang kehidupan sehar-hari terutama fasilitas yang berkaitan dengan kesehatan. Selain itu, ustad, kyai dan badal merupakan role model dari santri yang sering mencontoh pesantren yang diikuti perilakunya oleh santrinya terutama perilaku sehat sehingga perilaku kesehatan tersebut menjadi suatu kebiasaan. Beberapa penelitian juga menyebutkan terdapat hubungan antara keterbatasan fasilitas dan sarana yang dimiliki oleh pesantren dengan semangat hidup para santri dengan orang-orang di luar pesantren. Hal tersebut mengandung makna bahwa hidup merupakan suatu perjuangan, baik perjuangan ekonomi maupun perjuangan menyebarkan agama islam dalam situasi ataupun kondisi yang tidak mendukung bagi mereka (Ikhwanuddin, 2013).

PHBS disekolah atau pesanteren merupakan suatu upaya yang bertujuan untuk memberdayakan seluruh anggota masyarakat sekolah baik siswa, guru, dan masyarakat lingkungan sekolah agar tahu, mau dan mampu mempraktikan PHBS, dan berperan aktif dalam mewujudkan sekolah sehat. Ada beberapa indicator PHBS di Sekolah diantaranya. Mencuci tangan dengan air yang mengalir dan memakai sabun, Mengkonsumsi jajanan sehat di kantin sekolah, Menggunakan jamban yang bersih dan sehat, Olahraga yang teratur dan terukur, Memberantas jentik nyamuk, Tidak merokok di sekolah, Menimbang berat badan dan mengukur tinggi badan setiap bulan, Membuang sampah pada tempatnya. Ada beberapa hal yang dapat terjadi apabila kondisi santri tidak menerapkan PHBS di pesantren diantaranya penyakit kulit dan beberapa penyakit lainnya.

Salah satu indikator PHBS yaitu bebas Jentik. Seiring dengan semakin banyaknya kasus DBD, pemerintah membuat beberapa kebijakan terhadap pencegahan DBD yaitu dengan meningkatkan Sistem Kewaspadaan Dini (SKD) dan pengendalian vektor yang dilakukan dengan baik, terpadu dan 
berkesinambungan. Salah satu bentuk pengendalian nyamuk tersebut melalui kegiatan pemberantasan sarang nyamuk (PSN) melalui jumantik. Keberhasilan terhadap kegiatan PSN tersebut dapat dilihat apabila Angka Bebas Jentik (ABJ) di daerah tersebut lebih atau sama dengan 95\%. Hal tersebut merupakan indicator yang diharapkan dapat terpenuni di seluruh tatanan, sehingga penularan DBD dapat dicegah atau dikurangi.

Provinsi Jambi merupakan salah satu provinsi yang cukup tinggi kasus DBD. Pada tahun 2017 sebanyak 378 kasus dengan Insiden Rate 10,75 per 100.000 penduduk dan jumlah kematian sebanyak orang dengan CFR 0,53\% (Kemenkes, 2018). Kota Jambi adalah daerah dengan jumlah kasus tertinggi untuk kejadian DBD. Insiden Rate Kota Jambi pada tahun 2014 sebanyak 115,52 per 100.000 turun menjadi 80,65 per 100.000 penduduk tahun 2015 . Namun terjadi tren peningkatan yang significant pada tahun 2016, IR pada tahun 2016 meningkat menjadi 485, 5 per 100.000 penduduk (Dinkes Jambi, 2017). Tingginya angka insidensi tersebut menjadi tolak ukur belum optimalnya upaya pengendalian dan pencegahan penyakit DBD. Pondok pesantren Wadi Muqoddas merupakan

\section{LANDASAN TEORI}

\section{A. Perilaku Hidup Bersih dan Sehat (PHBS)}

PHBS merupakan singkatan dari Pola Hidup Bersih dan Sehat. Sedangkan pengertian PHBS adalah semua perilaku kesehatan yang dilakukan karena kesadaran pribadi sehingga keluarga dan seluruh anggotanya mampu menolong diri sendiri pada bidang kesehatan serta memiliki peran aktif dalam aktivitas masyarakat. salah satu pondok pesanren yang ada di Pondok Meja. Berdasarkan hasil survei awal, aspek perilaku terutama higiene personal santri pesantren tersebut masih kurang. Selain itu, lingkungan pondok pesantren tersebut juga belum bersih dan sehat karena masih banyak sampah sampah yang berserakan. Hal tersebut dapat menjadi faktor risiko tempat berkembang biakannya nyamuk.

Promosi kesehatan merupakan suatu proses untuk meningkatkan kemampuan masyarakat dalam mengendalikan dan meningkatkan keadaan sehat, seseorang atau kelompok dan harus mampu mengidentifikasi dan menyadari aspirasi, serta mampu memenuhi kebutuhan dan perubahan atau mengendalikan lingkungan (Notoadmojo, 2010). Salah satu strategi yang dapat dilakukukan promosi kesehatan adalah melalui komunikasi, informasi dan edukasi (KIE). Edukasi tersebut bertujuan meningkatkan pengetahuan santri mengenai PHBS dan berpengaruh terhadap perilaku sehat santri. Selain itu, melalui peningkatan kapasitas santri juga diharapkan dapat meningkatkan keterampilan santri dalam berperilaku sehat.

Perilaku hidup bersih sehat pada dasarnya merupakan sebuah upaya untuk menularkan pengalaman mengenai pola hidup sehat melalui individu, kelompok ataupun masyarakat luas dengan jalur-jalur komunikasi sebagai media berbagi informasi. Ada berbagai informasi yang dapat dibagikan seperti materi edukasi guna menambah pengetahuan serta meningkatkan sikap dan perilaku terkait cara hidup yang bersih dan sehat. 
PHBS adalah sebuah rekayasa sosial yang bertujuan menjadikan sebanyak mungkin anggota masyarakat sebagai agen perubahan agar mampu meningkatkan kualitas perilaku sehari - hari dengan tujuan hidup bersih dan sehat. Terdapat langkah langkah berupa edukasi melalui pendekatan pemuka atau pimpinan masyarakat, pembinaan suasana dan juga pemberdayaan masyarakat dengan tujuan kemampuan mengenal dan tahu masalah kesehatan yang ada di sekitar; terutama pada tingkatan rumah tangga sebagai awal untuk memperbaiki pola dan gaya hidup agar lebih sehat.

Tujuan utama dari gerakan PHBS adalah meningkatkan kualitas kesehatan melalui proses penyadartahuan yang menjadi awal dari kontribusi individu individu dalam menjalani perilaku kehidupan sehari - hari yang bersih dan sehat. Manfaat PHBS yang paling utama adalah terciptanya masyarakat yang sadar kesehatan dan memiliki bekal pengetahuan dan kesadaran untuk menjalani perilaku hidup yang menjaga kebersihan dan

\section{METODE PELAKSANAAN}

Pelaksanaan kegiatan pengabdian masyarakat ini dilakukan dalam beberapa tahap kegiatan sebagai berikut

\section{a. Tahap Persiapan}

Tahap ini mencakup segala kegiatan yang berhubungan persiapan sebelum pelaksanaan kegiatan. Tahapan ini terdiri atas:

1. Melakukan analisis situasi dan studi pendahuluan lokasi kegiatan

2. Melakukan koordinasi dan penyelesaian administrasi dengan mitra

3. Melakukan koordinasi dengan tim dosen pengabdian masyarakat memenuhi standar kesehatan. (Kemenkes 2020)

\section{B. Teori Perilaku Beralasan (Theory of Reasoned Action)}

Karakteristik reaksi perilaku manusia yang menarik adalah sifat diferensialnya yaitu satu stimulus dapat menimbulkan leih dari satu respon yang sama. Theory of Reasoned Action dikembangkan oleh Ajzen dan Fishben. Teori menyebabkan bahwa seseorang akan melakukan suatu perbuatan apabila ia memandang perbuatan itu positif dan bila ia percaya bahwa orang lain ingin agar ia melakukannya (Kusumaningrum 2017). Teori tindakan beralasan juga mengatakan bahwa sikap mempengaruhi perilaku melalui suatu proses pengambilan keputusa yang teliti dan beralasan. Komponen yang mempengaruhi yaitu sikap yang spesifik terhadap sesuatu, norma subjektif, dan sikap terhadap suatu perilaku bersama dengan norma subjektif.

4. Melakukan penggandaan angket mengenai pengetahuan peserta

5. Menyiapkan materi edukasi

\section{b. Tahap Pelaksanaan}

1. Melakukan pertemuan dengan pihak pesantren

2. Melakukan Edukasi PHBS

3. Melakukan Edukasi Demam Berdarah (DBD)

4. Pembentukan Kader Jumantik

5. Monitoring dan evaluasi hasil pelaksanaan. Evaluasi kegiatas dilakukan dengan menggunakan lembar kuesioner pre dan post test. Tahap pre test dilakukan sebelum kegiatan intervensi dan post test 
dilakukan sehari setelah kegiatan intervensi.

\section{c. Partisipasi Mitra}

1. Mengumpulkan santri untuk KIE

2. Menyediakan tempat kegiatan KIE

3. Menyediakan sarana dan prasarana KIE

\section{d. Keterkaitan}

Kegiatan ini ikut mendukung terciptanya kesehatan masyarakat melalui penyehatan diri (hygiene personal) dan menciptakan lingkungan yang kondusif dan sehat di Pondok Pesantren. Selain itu, dengan adanya peer educator dan kader jumantik dapat membantu pemerintah daerah dalam memantau perkembangan nyamuk di institusi pendidikan khususnya pesantren dan secara tidak langsung dapat menurunkan prevalensi kasus Demam Berdarah di Provinsi Jambi.

\section{METODE PENDEKATAN}

Adapun metode pendekatan yang digunakan dalam kegiatan pengabdian masyarakat ini sebagai berikut:

1. Melakukan advokasi kepada pengurus dan tokoh agama pesantren Al Muqodass untuk mendapatkan dukungan partisipasi masyarakat pesantren.

2. Melakukan pertemuan dan sosialiasi kepada santri terkait kegiatan yang akan dilakukan.

3. Melakukan koordinasi dan komunikasi menggukan media whatapp dengan pihak pesantren

\section{PROSEDUR KEGIATAN}

Adapun prosedur kegiatan yang dilaksanakan antara lain

1. Mempersiapkan tempat kegiatan.

2. Mobilisasi peserta kegiatan.

3. Penyampaian Maksud dan Tujuan Kegiatan

4. Pelaksanaan Pre Test.

5. Penyampaian Materi

6. Evaluasi Kegiatan

pengetahuan mereka sebelum terpapar informasi mengenai PHBS. Berdasarkan hasil pre-test diperoleh tingkat pengetahuan santri sebesar $50 \%$. Literasi mengenai PHBS juga terbilang rendah. Hal ini disebabkan kurangnya paparan informasi yang didapatkan mengenai PHBS. Berdasarkan hasil wawancara juga menyebutkan bahwa sebagian besar belum mengetahui PHBS dan baru pertama kali mendapatkan informasi tersebut. Setelah diberikan intervensi berupa edukasi menunjukkan peningkatan pengetahuan sebesar $90 \%$. Hal ini menunjukkan terjadi perbedaan tingkat pengetahuan sebelum dan sesudah dilakukan edukasi. 


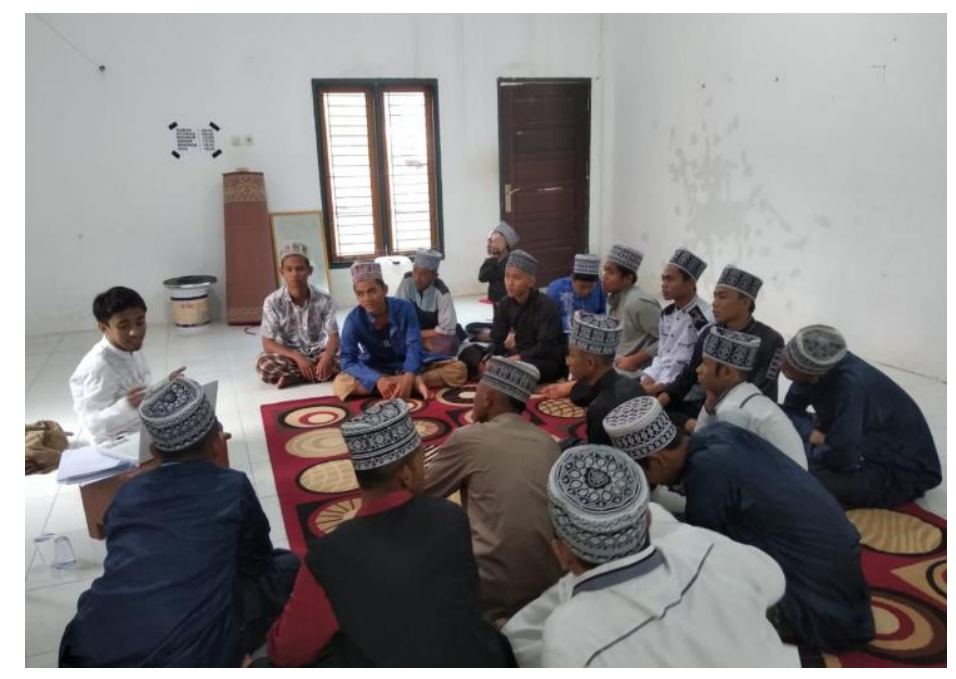

Gambar 1. Penyampaian Materi PHBS

oleh La Ode Reskiaddin, SKM.,MPH

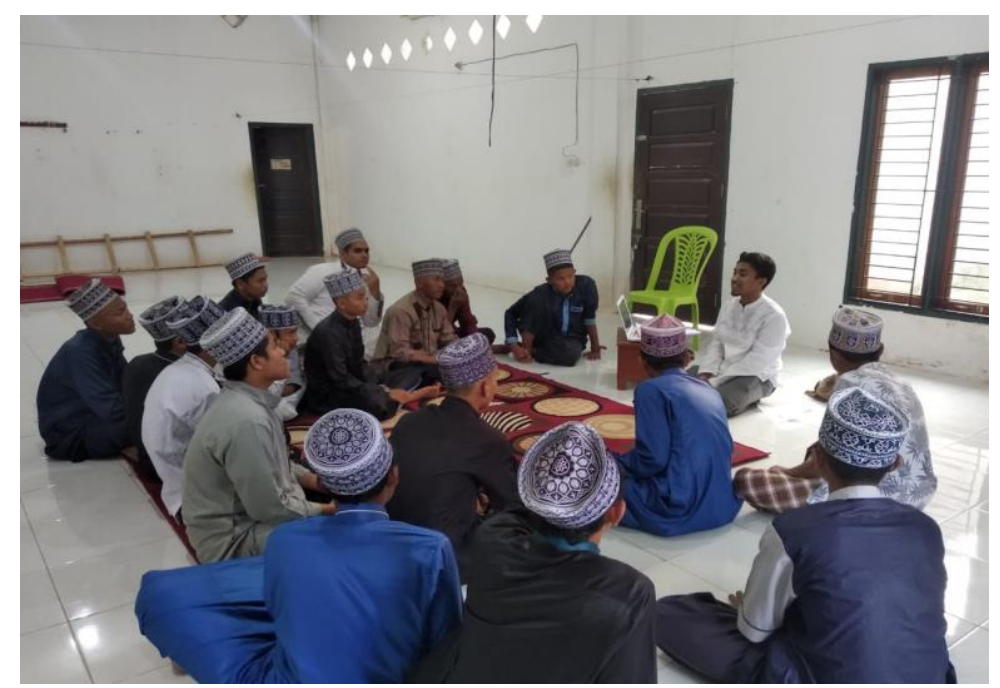

Gambar 2 Proses Diskusi dan Tanya Jawab

Hari kedua berfokus pada edukasi penyakit demam berdarah dan simulasi pemantauan jentik. Berdasarkan hasil diskusi dengan santri, pemahaman mengenai penyakit demam berdarah lebih baik setelah dilakukan edukasi dan simulasi dibandingkan sebelum diberi edukasi. Hal ini dilihat dari respon santri ketika diberi pertanyaan mengenai penyakit deman berdarah. Selain itu, pada hari kedua juga dibentuk tim kader jumantik. 


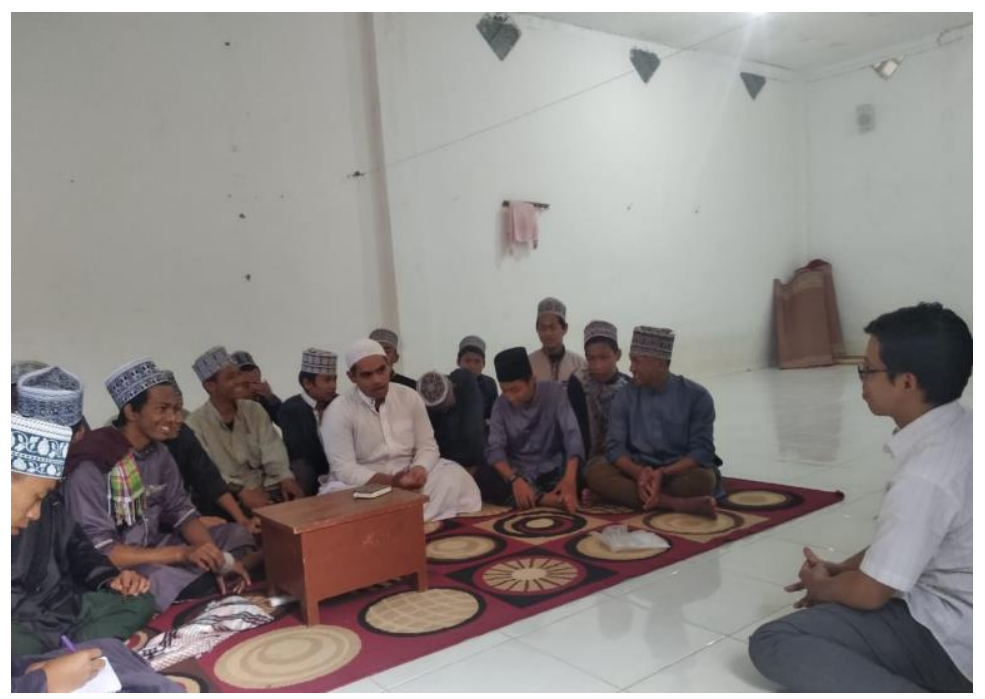

Gambar 3 Penyampaian Materi DBD dan Bimbingan Kader Jumantik oleh drh. David Kusmawan, MKKK.

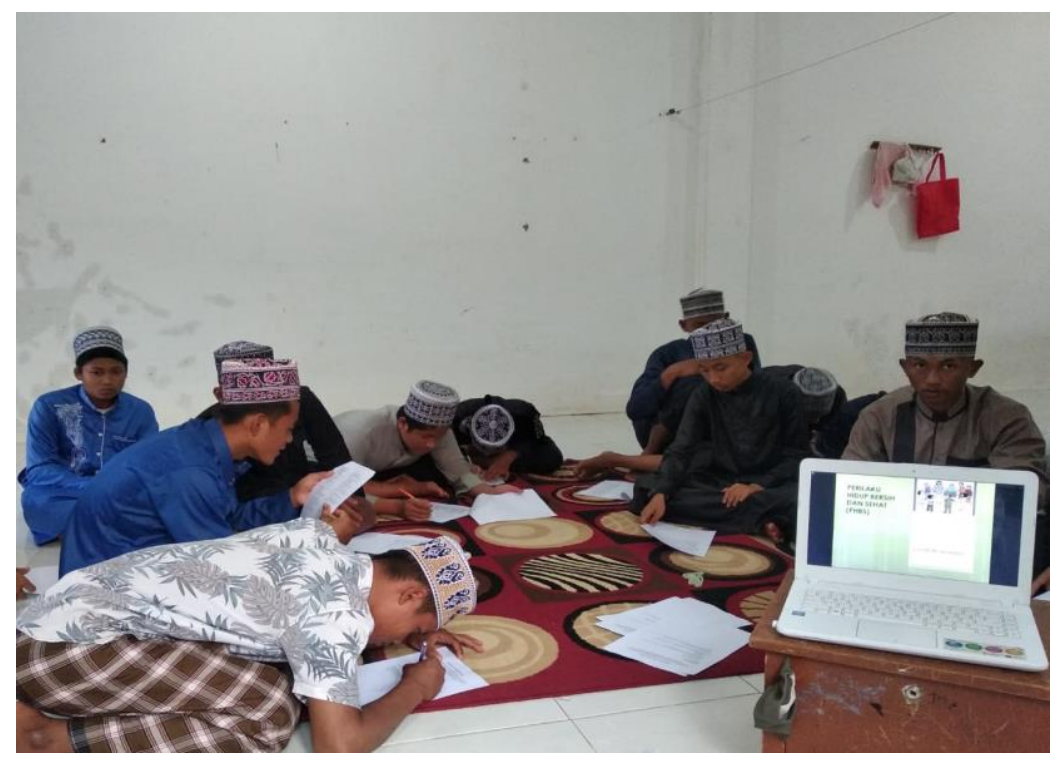

Gambar 4 Evaluasi Kegiatan Melalui Pengisian Pre-Post Test 
Hasil tahapan pelaksanaan kegiatan pengabdian kepada masyarakat di Pesantren Al Muqoddas sebagai berikut :

Tabel 1. Tahapan pelaksanaan kegiatan pengabdian kepada masyarakat

\begin{tabular}{|c|c|c|c|c|c|}
\hline No & Tahapan Kegiatan & Metode & Target Luaran & Tolak Ukur & Sasaran \\
\hline 1 & $\begin{array}{l}\text { Melakukan } \\
\text { pertemuan dengan } \\
\text { pihak pesantren }\end{array}$ & $\begin{array}{l}\text { Diskusi dan } \\
\text { advokasi }\end{array}$ & $\begin{array}{c}\text { Pemahaman } \\
\text { Pemilik Pesantren } \\
\text { dan Ustad } \\
\text { mengenai kegiatan } \\
\text { yang dilakukan }\end{array}$ & $\begin{array}{c}\text { Dukungan dan Partispasi } \\
\text { masyarakat pesantren }\end{array}$ & $\begin{array}{c}\text { Pemilik Pesantren } \\
\text { dan Ustad }\end{array}$ \\
\hline 2 & $\begin{array}{l}\text { Edukasi Mengenai } \\
\text { PHBS }\end{array}$ & $\begin{array}{c}\text { Ceramah } \\
\text { Tanya jawab, } \\
\text { diskusi } \\
\text { kelompok }\end{array}$ & $\begin{array}{l}\text { Terlaksananya } \\
\text { edukasi PHBS }\end{array}$ & $\begin{array}{c}\text { Materi edukasi dapat } \\
\text { dipahami dan diterima } \\
\text { dengan baik }\end{array}$ & Santri \\
\hline 3 & $\begin{array}{l}\text { Edukasi mengenai } \\
\text { Demam Berdarah }\end{array}$ & $\begin{array}{c}\text { Ceramah } \\
\text { Tanya jawab, } \\
\text { diskusi } \\
\text { kelompok }\end{array}$ & $\begin{array}{l}\text { Terlaksananya } \\
\text { edukasi DBD }\end{array}$ & $\begin{array}{c}\text { Materi edukasi dapat } \\
\text { dipahami dan diterima } \\
\text { dengan baik }\end{array}$ & Santri \\
\hline 4 & $\begin{array}{l}\text { Membentuk Kader } \\
\text { Jumantik Cilik }\end{array}$ & Diskusi & $\begin{array}{c}\text { Terbentuknya } \\
\text { Kader Jumantik } \\
\text { Cilik }\end{array}$ & $\begin{array}{c}\text { Terbentuknya pengurus } \\
\text { kader }\end{array}$ & Santri \\
\hline 5 & $\begin{array}{l}\text { Simulasi dalam } \\
\text { memantau Jentik }\end{array}$ & $\begin{array}{c}\text { Ceramah } \\
\text { Tanya jawab, } \\
\text { diskusi } \\
\text { kelompok } \\
\text { Praktek }\end{array}$ & $\begin{array}{c}\text { Telaksananya } \\
\text { Simulasi dalam } \\
\text { memantau Jentik }\end{array}$ & $\begin{array}{c}\text { Materi dapat } \\
\text { diaplikasikan melalui } \\
\text { demostrasi }\end{array}$ & Santri \\
\hline 6 & $\begin{array}{l}\text { Evaluasi dan } \\
\text { monitoring }\end{array}$ & $\begin{array}{l}\text { Bimbingan } \\
\text { dan sharing }\end{array}$ & $\begin{array}{l}\text { Peningkatan } \\
\text { pengetahuan dan } \\
\text { keterampilan }\end{array}$ & $\begin{array}{c}\text { Terjadi Peningkatan } \\
\text { pengetahuan dan } \\
\text { keterampilan }\end{array}$ & Santri \\
\hline
\end{tabular}

\section{KESIMPULAN DAN SARAN}

Penerapan promosi kesehatan masyarakat melalui komunikasi, informasi, dan edukasi (KIE) merupakan salah satu langkah praktis dan tepat untuk meningkatkan kapasitas dan literasi kesehatan masyarakat di bidang Perilaku Hidup Bersih dan Sehat santri Pesantren Wadi Muqoddas Pondok Meja, Provinsi Jambi. Selain itu agar program KIE ini bisa terus berlanjut maka langkah-langkah seperti pemberdayaan, pembentukan, dan penguatan kader santri untuk meneruskan praktik dan ilmu pengetahuan ini kepada sebayanya sangatlah diperlukan. Programprogram pemerintah terkait kesehatan masyarakat di lingkungan pondok pesantren di wilayah Jambi juga perlu diperkuat. 


\section{DAFTAR PUSTAKA}

Dinas Kesehatan Provinsi Jambi. 2017. Profil Kesehatan Kota Jambi.

Notoatmodjo, Soekidjo. 2010. Kesehatan Masyarakat Ilmu dan Seni. Jakarta : Rineka Cipta,

Kemenkes. (2018a). Data Dan Informasi Profil Kesehatan Indonesia 2017. Kementerian Kesehatan RI. Kementerian Kesehatan Republik Indonesia
Kemenkes. (2018b). Profil Kesehatan Indonesia 2017. Kementerian Kesehatan Republik Indonesia

Ikhwanuddin, A. 2013. Perilaku Kesehatan Santri : (Studi Deskriptif Perilaku Pemeliharaan Kesehatan , Pencarian Dan Penggunaan Sistem Kesehatan Dan Perilaku Kesehatan Lingkungan Di Pondok Pesantren Assalafi Al Fithrah, Surabaya). Departemen Sosiologi, FISIP, Universitas Airlangga 